\title{
Soil physical properties and yield of soybean and corn grown with wastewater
}

\author{
Alexsandro C. dos S. Almeida ${ }^{1}$, Higor H. O. Santos², Dhiego P. Bortolo², \\ Elaine R. P. Lourente ${ }^{2}$, Jorge W. Cortez ${ }^{2} \&$ Fabricio C. de Oliveira ${ }^{2}$ \\ ${ }^{1}$ Universidade Federal de Alagoas/Centro de Ciências Agrárias. Maceió, AL. E-mail: almeidaacs@yahoo.com.br (Corresponding author) - ORCID: 0000- \\ 0002-9389-1572 \\ ${ }^{2}$ Universidade Federal da Grande Dourados/Faculdade de Ciências Agrárias. Dourados, MS. E-mail: higorufgd@gmail.com - ORCID: 0000-0001-7877-2332; \\ dhiego_bt@hotmail.com - ORCID: 0000-0002-6806-3142; elainelourente@ufgd.edu.br - ORCID: 0000-0001-5658-7902; jorgecortez@ufgd.edu.br - ORCID: \\ 0000-0003-1120-719X; fabriciooliveira@ufgd.edu.br - ORCID: 0000-0002-7373-0667
}

\section{Key words:}

organic fertilization

soil physics

waste treatment

\begin{abstract}
A B S T R A C T
This study aimed to evaluate soybean and corn yields and soil physical attributes of a Dystrophic Red Latosol fertilized with swine wastewater (SW). Therefore, a field experiment was conducted in randomized blocks to evaluate five treatments of fertilization in the 2014/2015 season (soybean in the summer and corn in the second season). The treatments were: T1 - control (fertilized exclusively with chemical fertilizers); T2 - fertilized with $1270 \mathrm{~m}^{3} \mathrm{ha}^{-1}$ of SW; T3 - fertilized with $170 \mathrm{~m}^{3} \mathrm{ha}^{-1}$ of SW; T4 - fertilized with $50 \mathrm{~m}^{3} \mathrm{ha}^{-1}$ of SW; and T5 - fertilized with $50 \mathrm{~m}^{3} \mathrm{ha}^{-1}$ of SW + chemical fertilization. Soil samplings and soil physical analyses were performed before soybean cultivation and after corn harvest. No significant alteration was observed in soil physical attributes during the evaluation period. The application of swine wastewater in the fertilization of soybean and corn, cultivated in Dystrophic Red Latosol with high clay contents, positively affected these crops, since it led to good yields in soybean (with an average of $2990.85 \mathrm{~kg} \mathrm{ha}^{-1}$ ) and increased corn yields (with a maximum of $7126.5 \mathrm{~kg} \mathrm{ha}^{-1}$ ). In addition, soil physical properties were not altered.
\end{abstract}

\section{Palavras-chave:} adubação orgânica física do solo tratamento de dejetos

\section{Atributos físicos do solo e produtividades de soja e milho cultivadas com água residuária}

\begin{abstract}
R E S U M O
Objetivou-se avaliar as produtividades de soja, milho e os atributos físicos de um Latossolo Vermelho Distroférrico fertilizado com água residuária de suinocultura (ARS). Para isso, foi realizado um experimento a campo utilizando o delineamento em blocos casualizados. Foram avaliados cinco tratamentos de adubação na safra 2014/2015 (soja no verão e milho segunda safra). Os tratamentos foram: T1 - Controle (fertilizado exclusivamente com adubação química); T2 - Fertilizado com $1270 \mathrm{~m}^{3} \mathrm{ha}^{-1}$ de ARS; T3 - fertilizado com $170 \mathrm{~m}^{3} \mathrm{ha}^{-1}$ de ARS; T4 - Fertilizado com $50 \mathrm{~m}^{3} \mathrm{ha}^{-1}$ de ARS; e, T5 - Fertilizado com $50 \mathrm{~m}^{3} \mathrm{ha}^{-1}$ de ARS mais adubação química. Amostragens e análises físicas de solo foram realizadas antes do cultivo da soja e após a colheita do milho. Em relação aos atributos físicos do solo, não houve alterações significativas durante o período avaliado. A aplicação de água residuária de suinocultura na fertilização dos cultivos de soja e milho, cultivadas num solo Latossolo Vermelho Distroférrico com alto teor de argila, influenciaram positivamente esses cultivos, uma vez que proporcionou boas produtividades para soja (com média de 2990,85 $\mathrm{kg} \mathrm{ha}^{-1}$ ) e incremento de produtividade para o milho (com máxima de $7126,5 \mathrm{~kg} \mathrm{ha}^{-1}$ ). Além disso, os atributos físicos do solo não foram alterados.
\end{abstract}




\section{INTRODUCTION}

The use of swine wastes in the fertilization of crops is one form of adequate final disposal of wastes (Comin et al., 2013), since they are rich in nutrients that are essential to plants, such as phosphorus, potassium, calcium and magnesium (Manna et al., 2007; Celik et al., 2010). Thus, adequate and well planned application becomes an effective option to completely replace (Seidel et al., 2010; Sartor et al., 2012; Moraes et al., 2014) or partially replace industrialized mineral fertilizers (Passarin et al., 2016). This may reduce production costs and at the same time increase the availability of water and nutrients to plants.

Application of swine wastewater (SW) should be carried out in a controlled manner, avoiding contaminations and undesirable alterations in soil physical properties. Soil aggregation is the main physical attribute that can be affected by inadequate application of SW (Arruda et al., 2010), which can alter soil porosity, bulk density and resistance to penetration (Bandyopadhyay et al., 2010).

SW application can maintain soil physical quality (Agne \& Klein, 2014), contributing to the reduction of bulk density (Celik et al., 2010), increase of porosity (Hati et al., 2007) and, consequently, increase in water infiltration and retention in the soil. This occurs because of the increment in aggregate stability caused by the addition of organic matter (Arruda et al., 2010).

Thus, the definition of adequate doses of SW for the cultivation of plants becomes fundamental to guarantee maintenance and/or improvement in soil physical parameters. In addition, the dose should contribute to obtaining good yields. This study aimed to evaluate the effect of SW application on soil physical attributes and on the production parameters of soybean and corn crops.

\section{Material AND Methods}

The experiment was carried out in the 2014/2015 season at the Santa Clara Farm, in the municipality of Dourados, Mato Grosso do Sul state, located at latitude $22^{\circ} 13^{\prime} 16^{\prime \prime} \mathrm{S}$, longitude $54^{\circ} 48^{\prime} 20^{\prime \prime} \mathrm{W}$ and altitude of $430 \mathrm{~m}$. The climate is Aw, with dry winter, mean annual rainfall of $1500 \mathrm{~mm}$ and mean temperature of $22{ }^{\circ} \mathrm{C}$ (Alvares et al., 2013). The soil is classified as very clayey Dystroferric Red Latosol.

The experiment was conducted in randomized blocks with five treatments and four replicates, totaling 20 plots, with area of $120 \mathrm{~m}^{2}(10 \times 12 \mathrm{~m})$. Five treatments of fertilization were tested in the 2014/2015 season (soybean in the summer and corn in the second season). Treatments were: T1 - control (fertilized exclusively with chemical fertilization, $250 \mathrm{~kg} \mathrm{ha}^{-1}$ of the fertilizer 02-20-18); T2 - fertilized with $1270 \mathrm{~m}^{3} \mathrm{ha}^{-1}$ of SW; T3 - fertilized with $170 \mathrm{~m}^{3} \mathrm{ha}^{-1}$ of SW; T4 - fertilized with $50 \mathrm{~m}^{3} \mathrm{ha}^{-1}$ of SW; and, T5 - fertilized with $50 \mathrm{~m}^{3} \mathrm{ha}^{-1}$ of SW + chemical fertilization. The contents of phosphorus and potassium were used to determine the doses of SW in the treatments T2 and T3. The SW doses of $50 \mathrm{~m}^{3} \mathrm{ha}^{-1}$ is the minimum dose applied in the studied region.

Two crops were conducted (soybean - summer and corn - second season). Soybean was sown on October 22, 2014, using the cultivar 'BMX Potência' from Brasmax. Soybean was mechanically sown at spacing of $0.45 \mathrm{~m}$ between rows with approximately 15 seeds per meter. After soybean was harvested, corn was planted at spacing of $0.90 \mathrm{~m}$ between rows with six seeds per meter, using the cultivar 'Fórmula' from Syngenta, on February 15, 2015. Corn was harvested on July 15, 2015.

SW applications were carried out on soil surface soon after the sowing of each crop. SW was collected at the same farm where the experiment was conducted, in the third settling pond of swine farming wastewater. SW samples were analyzed at the laboratory to determine the physicochemical properties (Table 1), following the methodology described by Macêdo (2003). On average, the SW contained $2100 \mathrm{Mg} \mathrm{L}^{-1}$ of total dissolved solids (TDS). The different doses of SW were applied manually using 20-L plastic pots. In the treatments T3, T4 and T5, the doses were applied all at once after sowing. In the treatment T2, the dose was split into three applications, with intervals of one week between applications.

Soil samples were collected in all plots of the experiment before soybean sowing (early October 2014) and after corn harvest (August 2015). A soil pit (50 x $50 \times 50 \mathrm{~cm}$ of width, length and depth) was opened in each plot to collect samples at three depths $(0-5,5-15$ and $15-30 \mathrm{~cm})$. In each soil layer, one sample was collected using a volumetric ring to determine soil porosity and bulk density, and another sample was collected in undisturbed blocks to determine wet aggregate stability, totaling 60 samples with rings and 60 samples in blocks in each evaluation.

Soil macroporosity, microporosity, bulk density and aggregate stability were determined. Soil bulk density (Ds), macroporosity (MA), microporosity (MI) were determined using the method of the volumetric ring with $50 \mathrm{~mm}$ diameter, $51 \mathrm{~mm}$ height and $100 \mathrm{~cm}^{3}$ volume. Soil porosity was determined based on the water retained in undisturbed soil samples subjected to $6 \mathrm{kPa}$ tension, at saturation point and after the soil was dried for $24 \mathrm{~h}$ at $104^{\circ} \mathrm{C}$, according to Claessen et al. (1997).

Aggregate stability was determined by wet sieving using $30-\mathrm{g}$ samples of the $4.75-\mathrm{mm}$ fraction obtained by dry sieving. Samples containing aggregates and loose earth were placed on a set of sieves with meshes of $9.45,4.76$ and $2.00 \mathrm{~mm}$, shaken on a mechanical vibration shaker for $1 \mathrm{~min}$, with $30 \%$ power. Then, the weight of aggregates retained in the $2.00-\mathrm{mm}$-mesh sieve was determined and subsequently, this reconstituted sample was used in the step of sieving in water.

Aggregate stability was determined by sieving in water, after a slow pre-wetting by capillarity on moistened filter paper (Claessen et al., 1997). Aggregate size classes were separated using sieves with meshes of 2, 1, 0.5, 0.25 and $0.10 \mathrm{~mm}$, subjected to vertical oscillation for $15 \mathrm{~min}$ (Kemper \& Chepil, 1965). After this time, the material retained in each sieve was separated with the aid of a water jet, placed in previously weighed and identified cans, and taken to the oven until constant weight. Mean geometric diameter (MGD) was calculated using Eq. 1.

Table 1. Physical chemical composition of the three samples of swine wastewater used in the experiment

\begin{tabular}{|c|c|c|c|c|c|c|c|c|}
\hline $\mathrm{NH}_{4}{ }^{+}$ & $\mathrm{NO}_{3}$ & $P$ & K & $\mathrm{Na}$ & $\mathrm{Ca}$ & $\mathrm{Mg}$ & TDS* & \multirow{2}{*}{$\mathrm{pH}$} \\
\hline \multicolumn{8}{|c|}{$\mathrm{mg} \mathrm{L}^{-1}$} & \\
\hline 77 & 8.5 & 233 & 72 & 432 & 92 & 88 & 2100 & \\
\hline
\end{tabular}

*Total dissolved solids 


$$
\operatorname{MGD}=\frac{\exp \left(\sum_{i=1}^{n} w i \log x i\right)}{\left(\sum_{i=1}^{n} w i\right)}
$$

where:

MGD - mean geometric diameter, mm;

$\mathrm{n} \quad$ - number of classes;

xi - mean diameter of the aggregate classes; and,

wi - weight of aggregates of each size class, $g$.

The final grain yield of soybean was determined by harvesting all plants from a $9 \mathrm{~m}^{2}$ area (four 5-m-long rows). To evaluate the other variables (plant height, number of pods, first pod height), 10 plants were randomly harvested in each plot. Corn yield was evaluated by harvesting a $10 \mathrm{~m}^{2}$ area. For the other parameters of the crop (plant height, straw/grain ratio), 5 plants were randomly collected. These evaluations were carried out during the harvests of the crops.

The results were subjected to analysis of variance by F test. Means were compared by Tukey test at 0.05 probability level between treatments and by T test $(\mathrm{p}<0.05)$ between the results of the physical attributes before and after SW applications. The analyses were carried out using the program Assistat (Silva \& Azevedo, 2016).

\section{Results AND Discussion}

In general, there were no significant statistical differences in the physical attributes in the layers of the soil profile (0-5,
5-15, 15-30 cm) (Table 2) with the application of SW doses, when the values of the attributes were compared before and after SW applications, within the treatments. However, when the values were compared between treatments, significant alterations were found in MGD caused by SW application in the superficial layers $(0-5$ and 5-15 cm). In the 0-5 cm layer, significant differences in MGD between treatments were observed only before the application, mainly due to the lower value of MGD in T5. With the application of SW, the values of MGD increased from 1.82 to $2.06 \mathrm{~mm}$ in T5, from 2.17 to 2.40 $\mathrm{mm}$ in $\mathrm{T} 2$ and from 2.14 to $2.29 \mathrm{~mm}$ in $\mathrm{T} 4$, with no significant differences in MGD. On the other hand, in the next layer (5$15 \mathrm{~cm}$ ), MGD increased (from 1.70 to $2.09 \mathrm{~mm}$ ) only in the treatment that received the highest dose (T2).

It has been reported in the literature that, in soils with low aggregate stability, the application of increasing doses of SW, after several years, promotes improvements, increasing the MGD of stable aggregates (Hati et al., 2007; Comin et al., 2013). In the present study, SW application caused slight increments of MGD in the 0-5 cm layer, and in the 5-15 cm layer the increment only occurred in the treatment under high dose of SW. This small response may have occurred because, even before SW application, the soil already had high values of MGD (1.62 to $2.60 \mathrm{~mm}$ ), which are similar to values obtained under natural conditions of Cerrado vegetation and in soils cultivated with Brachiaria (Fonseca et al., 2007), indicating good aggregation and good structural quality (Comin et al., 2013). This condition is probably due to the oxidic mineralogy and high clay content of the soil, which impart high aggregate stability (Arruda et al., 2010).

Table 2. Soil physical attributes: mean geometric diameter (MGD), bulk density, macroporosity and microporosity before and after application of swine wastewater

\begin{tabular}{|c|c|c|c|c|c|c|c|c|}
\hline \multirow{3}{*}{ Treatment } & \multirow{2}{*}{\multicolumn{2}{|c|}{ MGD (mm) }} & \multirow{2}{*}{\multicolumn{2}{|c|}{ Bulk density $\left(\mathrm{Mg} \mathrm{m}^{-3}\right)$}} & \multicolumn{2}{|c|}{ Macroporosity } & \multicolumn{2}{|c|}{ Microporosity } \\
\hline & & & & & & & & \\
\hline & Before & After & Before & After & Before & After & Before & After \\
\hline \multicolumn{9}{|c|}{$0-5 \mathrm{~cm}$ soil layer } \\
\hline T1 & $1.95 \mathrm{ab} \mathrm{A}$ & $2.05 \mathrm{aA}$ & $1.40 \mathrm{a} \mathrm{A}$ & 1.36 a $A$ & 10.43 a $\mathrm{A}$ & $8.62 \mathrm{a} \mathrm{A}$ & 46.02 a A & 40.72 a B \\
\hline $\mathrm{T} 2$ & $2.17 a b \mathrm{~A}$ & $2.40 \mathrm{a} \mathrm{A}$ & $1.50 \mathrm{a} \mathrm{A}$ & $1.51 \mathrm{a} A$ & 12.11 a $A$ & 6.75 a A & 41.67 a A & 44.15 a A \\
\hline T3 & 2.60 a $A$ & $2.15 \mathrm{a} \mathrm{A}$ & 1.46 a A & 1.45 a A & $11.02 \mathrm{a} A$ & 7.25 a $A$ & 44.94 a A & 42.31 a A \\
\hline T4 & $2.14 a b \mathrm{~A}$ & $2.29 \mathrm{a} \mathrm{A}$ & 1.40 a A & 1.46 a A & 11.83 a $A$ & $6.15 \mathrm{a} \mathrm{A}$ & 45.53 a $A$ & 42.44 a A \\
\hline $\mathrm{T} 5$ & 1.82 b A & 2.06 a $A$ & 1.35 a $\mathrm{A}$ & 1.55 a $A$ & 11.06 a $A$ & 6.35 a A & 35.62 a $A$ & 45.22 a $A$ \\
\hline Mean & & & 1.42 & 1.47 & & & & \\
\hline CV (\%) & & & 11.4 & 7.59 & & & & \\
\hline \multicolumn{9}{|c|}{$5-15 \mathrm{~cm}$ soil layer } \\
\hline $\mathrm{T} 1$ & $1.87 \mathrm{a} \mathrm{A}$ & $1.92 \mathrm{ab} \mathrm{A}$ & $1.51 \mathrm{a} \mathrm{A}$ & 1.50 a $\mathrm{A}$ & 5.39 a A & 7.34 a A & 41.69 a A & 43.75 a A \\
\hline T2 & $1.70 \mathrm{a} \mathrm{A}$ & 2.09 a A & $1.52 \mathrm{a} \mathrm{A}$ & 1.36 a A & $8.73 \mathrm{a} \mathrm{A}$ & 8.02 a A & 44.23 a $A$ & 42.36 a A \\
\hline T3 & $1.90 \mathrm{a} \mathrm{A}$ & $1.84 \mathrm{ab} A$ & $1.60 \mathrm{a} \mathrm{A}$ & 1.32 a $\mathrm{A}$ & 4.93 a $A$ & 5.86 a A & 47.32 a $A$ & 40.59 a $A$ \\
\hline T4 & $1.92 \mathrm{a} \mathrm{A}$ & $1.84 a b \mathrm{~A}$ & $1.51 \mathrm{a} A$ & 1.38 a $A$ & 14.79 a A & 9.20 a $A$ & 41.17 a A & 41.85 a $A$ \\
\hline T5 & 1.62 a $A$ & $1.67 \mathrm{bA}$ & $1.41 \mathrm{a} A$ & $1.41 \mathrm{a} \mathrm{A}$ & 6.53 a $A$ & 9.08 a $A$ & 47.58 a $A$ & 42.66 a $A$ \\
\hline Mean & & & 1.51 & 1.39 & & & & \\
\hline CV (\%) & & & 7.45 & 12.5 & & & & \\
\hline \multicolumn{9}{|c|}{$15-30 \mathrm{~cm}$ soil layer } \\
\hline $\mathrm{T} 1$ & 1.70 a $A$ & 1.74 a $A$ & 1.45 a $A$ & 1.26 a $A$ & $9.42 \mathrm{a} A$ & 11.06 a $\mathrm{A}$ & 46.08 a A & 42.93 a A \\
\hline T2 & $1.71 \mathrm{a} \mathrm{A}$ & 1.78 a A & $1.41 \mathrm{a} \mathrm{A}$ & 1.33 a A & 7.94 a A & 9.13 a A & 48.85 a $A$ & 44.70 a $A$ \\
\hline T3 & 1.74 a $\mathrm{A}$ & 1.96 a $\mathrm{A}$ & 1.36 a $\mathrm{A}$ & 1.36 a $A$ & 11.24 a $A$ & 10.12 a A & 45.90 a $A$ & 44.34 a A \\
\hline T4 & 1.89 a $A$ & 1.54 a $A$ & 1.38 a $A$ & 1.29 a A & 9.67 a A & 9.83 а A & 44.62 a A & 42.90 a $A$ \\
\hline $\mathrm{T} 5$ & 1.68 a $\mathrm{A}$ & 1.92 a $A$ & 1.39 a A & 1.25 a $A$ & 9.66 a $\mathrm{A}$ & 8.77 a $A$ & 45.53 a $A$ & 42.65 a $A$ \\
\hline Mean & & & 1.40 & 1.30 & & & & \\
\hline CV (\%) & & & 9.27 & 4.14 & & & & \\
\hline
\end{tabular}

Means followed by the same lowercase letter in the column do not differ significantly by Tukey test at 0.05 probability level; Means followed by the same uppercase letter in the line, compared within each treatment, before and after application, do not differ significantly by t-test: $\mathrm{T} 1<0.05)$; T1 - Control; T2 - $1270 \mathrm{~m}^{3}$ ha $^{-1}$ of swine wastewater $(\mathrm{SW})$; T3 - $170 \mathrm{~m}^{3}$ ha ${ }^{-1}$ of SW; $\mathrm{T} 4-50 \mathrm{~m}^{3} \mathrm{ha}^{-1}$ of SW; T5 $-50 \mathrm{~m}^{3} \mathrm{ha}^{-1}$ of SW + chemical fertilization 
Soil bulk density (Ds) was not changed by the applied doses of SW (Table 2). Ds varied from 1.25 to $1.60 \mathrm{Mg} \mathrm{m}^{-3}$, but there were no significant differences before and after SW application, or between the studied treatments. Other studies with SW application in the same type of soil (Arruda et al., 2010; Agne \& Klein, 2014) did not find changes in Ds with the application of SW. However, in soils with lower aggregate stability, Hati et al. (2007) and Comin et al. (2013) observed reduction in Ds after 8 and 20 years of SW application, respectively. These latter authors report that the reduction was due to the improvement in aggregate stability and incorporation of organic matter.

No significant differences in soil macroporosity and microporosity were observed between treatments, indicating that the applications of SW doses did not cause significant alterations in soil porosity. These results corroborate those of Arruda et al. (2010) and Veiga et al. (2012), who also found no alterations in the macroporosity of a Dystroferric Red Latosol, under application of SW doses of 50, 100 and $200 \mathrm{~m}^{3} \mathrm{ha}^{-1}$.

The total dissolved solids (TDS) in the SW used were approximately $2100 \mathrm{Mg} \mathrm{L}^{-1}$ (Table 1). This is a low concentration of TDS and provides small amount of organic matter to the soil, insufficient to cause alterations in soil porosity with only one application per cycle. Soil porosity is commonly altered by the application of solid wastes which provide a large amount of organic matter and increase microporosity (Hati et al., 2007; Manna et al., 2007; Celik et al., 2010).

In the soil of the experiment, the values of MGD, bulk density and porosity were within the optimal limits (Reynolds et al., 2002; Bandyopadhyay et al., 2010) for a sustainable production of soybean and corn for the type of soil studied (Agne \& Klein, 2014), and SW applications did not alter these important physical properties of the soil, maintaining its good physical quality.

The probable explanations for the lack of changes in soil physical properties are the low amount of TDS, short period of evaluation and good quality of the soil. The one-year period may have been insufficient for SW to cause changes in the structure, bulk density and porosity of the soil. Usually, modifications are observed after several years of applications (Hati et al., 2007; Comin et al., 2013). Another issue is that the soil already had a good physical quality before the application, due to the long period of cultivation under direct planting system (DPS). The DPS favors the formation of larger stable aggregates and the maintenance of the mean diameter of the stable aggregates (Salton et al., 2008).

For soybean, plant height was influenced by the application of the doses of SW (Table 3). The highest value of height was observed in the treatments with the highest dose of SW (T2). However, the difference between treatments was only $12 \mathrm{~cm}$ between the highest and lowest values of height. Alves Neto et al. (2016), analyzing the growth of soybean plants under increasing doses of SW, observed that higher doses led to greater vegetative development.

For first pod height (FPH), no differences were observed between treatments (Table 3). The mean value of FPH was $18.08 \mathrm{~cm}$ between treatments, a value considered as adequate for soybean because plants with FPH above $12 \mathrm{~cm}$ reduce losses at harvest, on flat areas (Amorim et al., 2011).
Table 3. Production parameters for soybean

\begin{tabular}{|ccccc}
\hline Treatments & $\begin{array}{c}\text { Plant } \\
\text { height } \\
(\mathbf{m})\end{array}$ & $\begin{array}{c}\text { First pod } \\
\text { height } \\
\mathbf{( c m )}\end{array}$ & $\begin{array}{c}\text { Number } \\
\text { of pods }\end{array}$ & $\begin{array}{c}\text { Yield } \\
\left(\mathbf{k g ~ h a}^{-1}\right)\end{array}$ \\
T1 & $1.04 \mathrm{~b}$ & $17.3 \mathrm{a}$ & $48.9 \mathrm{a}$ & $3061.9 \mathrm{a}$ \\
T2 & $1.16 \mathrm{a}$ & $18.3 \mathrm{a}$ & $55.0 \mathrm{a}$ & $3024.4 \mathrm{a}$ \\
T3 & $1.10 \mathrm{ab}$ & $18.5 \mathrm{a}$ & $45.7 \mathrm{a}$ & $2916.6 \mathrm{a}$ \\
T4 & $1.05 \mathrm{~b}$ & $19.5 \mathrm{a}$ & $47.4 \mathrm{a}$ & $3067.7 \mathrm{a}$ \\
T5 & $1.07 \mathrm{~b}$ & $16.9 \mathrm{a}$ & $53.0 \mathrm{a}$ & $2883.7 \mathrm{a}$ \\
Mean & 1.08 & 18.08 & 50.01 & 2990.85 \\
\hline CV (\%) & 3.56 & 7.75 & 12.05 & 5.70 \\
\hline
\end{tabular}

Means followed by the same lowercase letter in the column do not differ significantly by Tukey test at 0.05 probability level; T1 - Control; T2 $-1270 \mathrm{~m}^{3} \mathrm{ha}^{-1}$ of swine wastewater (SW) T3 - $170 \mathrm{~m}^{3} \mathrm{ha}^{-1}$ of SW; T4 $-50 \mathrm{~m}^{3} \mathrm{ha}^{-1}$ of SW; T5 $-50 \mathrm{~m}^{3} \mathrm{ha}^{-1}$ of SW + chemical fertilization

The number of pods and grain yield were not influenced by the type of fertilization (Table 3 ). The mean yield obtained between treatments was $2990.85 \mathrm{~kg} \mathrm{ha}^{-1}$ and is within the mean of the region. These results show that all SW doses applied were adequate to provide sufficient amount of nutrients to obtain good grain yields. Sartor et al. (2012) reported equal soybean yields between treatments fertilized with doses of $50 \mathrm{~m}^{3} \mathrm{ha}^{-1}$ of SW and $300 \mathrm{~kg} \mathrm{ha}^{-1}$ of NPK, in soil of the same type as the one in the present study. Hati et al. (2007) and Kessler et al. (2014) concluded that fertilization with SW in soybean cultivation can be an alternative form of fertilization in replacement to NPK fertilization.

For corn, many research results report vegetative development proportional to SW doses (Rezende et al., 2009; Alves Neto et al., 2016). In this study, there were no differences in plant height and straw/grain ratio between treatments (Table 4). However, grain yield was influenced by SW doses because, in the treatment with highest dose of SW (T2), grain yield was $9.2 \%$ higher than that of the control treatment. This increment could be greater because Prior et al. (2015) reported increase of up to $23 \%$ in yield with SW application associated with chemical fertilization (CF).

Other studies also found good grain yields in treatments with application of SW (Rezende et al., 2009; Comin et al., 2013) corroborating the data of the present study, and greater production response to SW application was observed in corn, compared with soybean. This occurs because corn is more responsive to organic fertilization than soybean (Hati et al., 2007; Manna et al., 2007; Moraes et al., 2014; Alves Neto et al., 2016).

Fertilization with SW allowed obtaining equal (soybean) and even higher (corn) grain yields compared with chemical fertilization. Similar yields between crops under CF and SW with doses from $60 \mathrm{~m}^{3} \mathrm{ha}^{-1}$ in clayey Red Latosols have been

Table 4. Production parameters for corn

\begin{tabular}{cccc}
\hline Treatments & $\begin{array}{c}\text { Plant height } \\
(\mathbf{m})\end{array}$ & Straw/grain ratio & $\begin{array}{c}\text { Yield } \\
\left.\mathbf{( k g ~ h a}^{-1}\right)\end{array}$ \\
T1 & $1.82 \mathrm{a}$ & $2.91 \mathrm{a}$ & $6526.0 \mathrm{~b}$ \\
T2 & $1.86 \mathrm{a}$ & $3.25 \mathrm{a}$ & $7126.5 \mathrm{a}$ \\
T3 & $1.72 \mathrm{a}$ & $3.46 \mathrm{a}$ & $6525.5 \mathrm{~b}$ \\
T4 & $1.75 \mathrm{a}$ & $3.16 \mathrm{a}$ & $6661.2 \mathrm{ab}$ \\
T5 & $1.84 \mathrm{a}$ & $2.88 \mathrm{a}$ & $6670.0 \mathrm{ab}$ \\
Mean & 1.80 & 3.13 & 6703.2 \\
CV (\%) & 11.23 & 14.28 & 3.86 \\
\hline
\end{tabular}

Means followed by the same lowercase letter in the column do not differ significantly by Tukey test at 0.05 probability level; $\mathrm{T} 1-$ Control; T2 $-1270 \mathrm{~m}^{3} \mathrm{ha}^{-1}$ of swine wastewater (SW); T3 $-170 \mathrm{~m}^{3} \mathrm{ha}^{-1}$ of SW; T4 $-50 \mathrm{~m}^{3} \mathrm{ha}^{-1}$ of SW; T5 $-50 \mathrm{~m}^{3} \mathrm{ha}^{-1}$ of SW + chemical fertilization 
reported (Seidel et al., 2010; Sartor et al., 2012; Moraes et al., 2014). Thus, CF in corn and soybean crops can be replaced by the application of SW doses.

The three doses applied can be used without causing alterations in soil physical properties in crops under DPS. It is worth highlighting that the application should be split for higher doses (greater than $1250 \mathrm{~m}^{3} \mathrm{ha}^{-1}$ ) to avoid runoff, because the application rate needs to be lower than the basic infiltration rate of the soil. Higher doses lead to higher cost and depend on the availability of SW, so that the greatest profits and maximum technical efficiencies are obtained with the application of SW doses from 70 to $100 \mathrm{~m}^{3} \mathrm{ha}^{-1}$ (Moraes et al., 2014; Alves Neto et al., 2016).

\section{Conclusions}

1. The application of swine wastewater in the fertilization of soybean and corn, grown in a Dystroferric Red Latosol with high clay content, positively influences these crops because it leads to adequate yields for soybean and increased yield for corn.

2. After one agricultural year of use, soil physical attributes were not altered by the application of swine wastewater.

\section{Acknowledgments}

The authors thank the FUNDECT (Fundação de Apoio ao Desenvolvimento do Ensino, Ciência e Tecnologia do Estado de Mato Grosso do Sul) for the support to carry out the study.

\section{Literature Cited}

Agne, S. A. A.; Klein, V. A. Matéria orgânica e atributos físicos de um Latossolo Vermelho após aplicações de dejeto de suínos. Revista Brasileira de Engenharia Agrícola e Ambiental, v.18, p.720-726, 2014. https://doi.org/10.1590/S1415-43662014000700008

Alvares, C. A.; Stape, J. L.; Sentelhas, P. C.; Gonçalves, J.; Sparovek, G. Köppen's climate classification map for Brazil. Meteorologische Zeitschrift, v.22, p.711-728, 2013. https://doi.org/10.1127/09412948/2013/0507

Alves Neto, A. J.; Lana, M. C.; Rampim, L.; Costa, L. A. de M.; Coppo, J. C.; Alves, A. G. Água residuária de suinocultura sobre a produtividade de soja e milho segunda safra: Uso e viabilidade econômica. Sciencia Agraria Paranaensis, v.15, p.350-357, 2016. https://doi.org/10.18188/1983-1471/sap.v15n3p350-357

Amorim, F. A.; Hamawaki, O. T.; Sousa, L. B.; Lana, R. M. Q.; Hamawaki, C. D. L. Época de semeadura no potencial produtivo de Soja em Uberlândia-MG. Semina: Ciências Agrárias, v.32, p.1793-1802, 2011. https://doi.org/10.5433/1679-0359.2011v32n4Sup1p1793

Arruda, C. A. O.; Alves, M. V.; Mafra, A. L.; Cassol, P. C.; Albuquerque, J. A.; Santos, J. C. P. Aplicação de dejeto suíno e estrutura de um Latossolo Vermelho sob semeadura direta. Ciência e Agrotecnologia, v.34, p.804-809, 2010. https://doi.org/10.1590/ S1413-70542010000400002

Bandyopadhyay, K. K.; Misra, A. K.; Ghosh, P. K.; Hati, K. M. Effect of integrated use of farmyard manure and chemical fertilizers on soil physical properties and productivity of soybean. Soil and Tillage Research, v.110, p.115-125, 2010. https://doi.org/10.1016/j. still.2010.07.007
Celik, I.; Gunal, H.; Budak, M.; Akpinar, C. Effects of long-term organic and mineral fertilizers on bulk density and penetration resistance in semi-arid Mediterranean soil conditions. Geoderma, v.160, p.236-243, 2010. https://doi.org/10.1016/j.geoderma.2010.09.028

Claessen, M. E. C.; Barreto, W. D. O.; Paula, J. D.; Duarte, M. N. Manual de métodos de análise de solo. 2.ed. Rio de Janeiro: Embrapa Solos, 1997. 212p.

Comin, J. J.; Loss, A.; Veiga, M. da; Guardini, R.; Schmitt, D. E.; Oliveira, P. A. V. de. Physical properties and organic carbon content of a Typic Hapludult soil fertilised with pig slurry and pig litter in a no-tillage system. Soil Research, v.51, p.459-470, 2013. https://doi.org/10.1071/SR13130

Fonseca, G. C.; Carneiro, M. A. C.; Costa, A. R.; Oliveira, G. C.; Balbino, L. C. Atributos físicos, químicos e biológicos de Latossolo de Cerrado sob duas rotações de cultura. Pesquisa Agropecuária Tropical, v.37, p.22-30, 2007.

Hati, K. M.; Swarup, A.; Dwivedi, A. K.; Misra, A. K.; Bandyopadhyay, K. K. Changes in soil physical properties and organic carbon status at the topsoil horizon of a vertisol of central India after 28 years of continuous cropping, fertilization and manuring. Agriculture, Ecosystems \& Environment, v.119, p.127-134, 2007. https://doi. org/10.1016/j.agee.2006.06.017

Kemper, W. D.; Chepil, W. S. Size distribution of aggregates. In: Black, C. A.; Evans, D. D.; White, J. L. (eds.). Methods of soil analysis. Part 1: Physical and mineralogical properties, including statistics of measurement and sampling. Madison: American Society of Agronomy, 1965. p.499-510.

Kessler, N. C. H.; Sampaio, S. C.; Sorace, M.; Lucas, S. D.; Palma, D. Swine wastewater associated with mineral fertilization on corn crop (Zea mays). Engenharia Agrícola, v.34, p.554-566, 2014. https://doi.org/10.1590/S0100-69162014000300018

Macêdo, J. A. B. Métodos laboratoriais de análises físico-químicas e microbiológicas. 2.ed. Belo Horizonte: Conselho Regional de Química, 2003.450p.

Manna, M. C.; Swarup, A.; Wanjari, R. H.; Mishra, B.; Shahi, D. K. Long-term fertilization, manure and liming effects on soil organic matter and crop yields. Soil \& Tillage Research, v.94, p.397-409, 2007. https://doi.org/10.1016/j.still.2006.08.013

Moraes, M. T. de; Arnuti, A.; Silva, V. R. da; Silva, R. F. da; Basso, C. J.; Ros, C. O. da. Dejetos líquidos de suínos como alternativa a adubação mineral na cultura do milho. Semina: Ciências Agrárias, v.35, p.2945-2954, 2014. https://doi.org/10.5433/1679$0359.2014 v 35 n 6 \mathrm{p} 2945$

Passarin, O. M.; Sampaio, S. C.; Rosa, D. M.; Reis, R. R. dos; Correa, M. M. Soybean nutritional status and seed physiological quality with swine wastewater. Revista Brasileira de Engenharia Agrícola e Ambiental, v.20, p.16-21, 2016. https://doi.org/10.1590/18071929/agriambi.v20n1p16-21

Prior, M.; Sampaio, S. C.; Nóbrega, L. A. H. P.; Dieter, J.; Costa, M. S. S. de M. Estudo da associação de água residuária de suinocultura e adubação mineral na cultura do milho e no solo. Engenharia Agrícola, v.35, p.744-755,2015. https://doi.org/10.1590/18094430-Eng.Agric.v35n4p744-755/2015

Rezende, A. V. de; Valeriano, A. R.; Vilela, H. H.; Cesarino, R. de O.; Salvador, F. M.; Silveira, C. H. Milho fertirrigado com dejetos líquidos de suínos para ensilagem. Revista Agrarian, v.2, p.7-20, 2009. 
Reynolds, W. D.; Bowman, B. T.; Drury, C. F.; Tan, C. S.; Lu, X. Indicators of good soil physical quality: Density and storage parameters. Geoderma, v.110, p.131-146, 2002. https://doi.org/10.1016/S0016-7061(02)00228-8

Salton, J. C.; Mielniczuk, J.; Bayer, C.; Boeni, M.; Conceição, P. C.; Fabrício, A. C. Agregação e estabilidade de agregados do solo em sistemas agropecuários em Mato Grosso do Sul. Revista Brasileira de Ciência do Solo, v.32, p.11-21, 2008. https://doi.org/10.1590/ S0100-06832008000100002

Sartor, L. R.; Assmann, A. L.; Assmann, S. T.; Bigolin, P. E.; Miyazawa, M.; Carvalho, P.C. de F. Effect of swine residue rates on corn, common bean, soybean and wheat yield. Revista Brasileira de Ciência do Solo, v.36, p.661-669, 2012. https://doi.org/10.1590/S0100-06832012000200035
Seidel, E. P.; Gonçalves Júnior, A. C.; Vanin, J. P.; Strey, L.; Schwantes, D.; Nacke, H. Aplicação de dejetos de suínos na cultura do milho cultivado em sistema de plantio direto. Acta Scientiarum. Technology, v.32, p.113-117, 2010.

Silva, F. de A. S. e; Azevedo, C. A. V. de. The Assistat software version 7.7 and its use in the analysis of experimental data. African Journal of Agricultural Research, v.11, p.3733-3740, 2016. https://doi. org/10.5897/AJAR2016.11522

Veiga, M.; Pandolfo, C. M.; Dortzbach. D.; Araújo, I. S. Atributos físicos do solo em glebas com aplicação continuada de dejeto líquido de suínos. Revista Agropecuária Catarinense, v.25, p.7478, 2012. 